\title{
An Inquiry into the Moral and Religious Dimensions of International Politics: the Thought and Contribution of Rui Barbosa
}

\section{Raphael Spode* $^{*}$}

Abstract: The purpose of this paper is to introduce the thought of Brazilian statesman Rui Barbosa (1849-1923) on foreign policy and international relations from the vantage point of doctrinal reflection. In recent years, scholars have thoroughly sought to find the existence of a distinct Brazilian national thinking, building on the premise that there is no great diplomacy without a consistent foreign policy perspective. Thus, it would be mandatory to search for ideas and reflections that had assisted the foreign policy construction of the country, considered by many as well succeeded in most respects. In this context, the paper seeks to identify the possible foundations of Rui Barbosa's vision on foreign policy and international relations, which is highlighted by a strong moral and religious foundation and settled on his contemporary conceptions on the pursuit of international peace. Keywords: Rui Barbosa; National Thinking on Foreign Policy; International Relations Theory; Philosophy and Ethics in Politics; History of Political Thought.

\section{Introduction}

The task of assessing Brazil's Old Republic era $(1889-1930)^{1}$ is of paramount importance if one is to grasp the principles that govern the country's foreign policy and which remain to this day unchanged, as seen in the fourth article of the 1988 Constitution. The contributions of José Paranhos, the 'Baron of Rio Branco' (1845-1920), ${ }^{2}$ are widely acknowledged and have been studied in depth, owing him the merits of being the 'father of Brazil's diplomacy. Maybe in virtue of his varied activities as a public figure, however, Rui Barbosa is relatively less acknowledged as an original pinnacle of international political thinking. In fact, despite his name being widely associated with the restoration of Brazil's international prestige - as is often symbolised through his participation as official envoy to the Second Hague Conference in 1907 - and remembered when accounting for the universalist vocation of Brazilian diplomacy, and remembered as well for his defence of the traditional

* University of Brasília and UniCEUB, Brasília-DF, Brazil; raphael.spode@gmail.com. 
principles regarding international law, Barbosa is usually considered under the shadow of the 'Rio Branco legacy' (Garcia 1996: 103).

Rui Barbosa never undertook direct participation in the decision-making process of Brazil's foreign affairs, nor did he ever systematically theorise on international politics, but he did leave a personal legacy and a wide range of perceptions related to the topic. Therefore, although the fact that his writings do not deal explicitly with theories and doctrines, it is possible to extract, through a scrutiny of this statesman's actions and intellectual manifestations, a significant contribution to critical thinking on Brazil's foreign policy. ${ }^{3}$ The purpose of this research is to look for, and in fact excavate, possible theoretical and doctrinal foundations on foreign policy as distributed in his parliamentary discourses and other oratory pieces, journal articles, institutional acts of the Republic, and technical notes. Our understanding is that a more careful reading of such pieces allows one to depict, pace Barbosa, a quite organic vision of international society, which presupposes a particular acquaintance with the nature and processes peculiar to the international realm - even when not systematically exposed by him (Garcia 1996: 103-4).

Surprisingly, few have taken the trouble to verify the extent to which it would have been plausible for someone who performed such a prominent role in the country's foreign activities, as is the case of Barbosa, to have done so without a consistent theoretical and doctrinal basis regarding the forces that were, or were supposed to be, actually moving the gears of international politics and, more specifically, Brazil's foreign policy. During the transition from the nineteenth to the twentieth century, Rui Barbosa was not only directly engaged with ongoing facts in international society, but also produced countless works, reports, and discourses over issues such as the distribution of power, border disputes, and events linked to international conflicts. In the context of the Old Republic, Barbosa is revered, both in Brazil and internationally, for his experience and vision of international society. Although he was widely known as the 'Eagle of The Hague', posterity ended up proclaiming there to be, effectively, no contribution of his thought to international politics, just as his records are usually considered to be the sole consequence of a man guided in the world of action:

Rui [Barbosa] starts off from a specific premise and crushes the contender; he castles himself inside his library as it were a fortress, and through his shelves he opens fire over his adversaries with those complicated words, with that marvelous machine of reasoning. Now, if a reader starts to search for his contributions, for his thought, I allow myself to say that he finds very little (Arios quoted in Cardim 2007: 24, author's emphasis).

Barbosa, just like many others of his time, was indeed characterised by a high level of erudition in his academic background and also by an excessive laureate formalism in the treatment of ideas and reality. To some authors, Barbosa's 'intellectualist' stance - relatively distanced from material reality, and influenced by a high level of abstraction - appears to be a deficiency (Fausto 1999; Garcia 1996: 106). It remains, nonetheless, necessary to consider that his puzzling images still retain, under the style of an era, deep visions of 
the country and of his own time, along with an axiological meaning that may be valuable and even desired to the movement of conceptual renewal that the discipline is currently turning its attention to. ${ }^{4}$

Concerning Rui Barbosa's thought on foreign policy and international relations, there has been agreement that it moves through at least three main thesis: the opposition to a differentiated treatment given to states according to their power status, which was defended during the Second Hague Conference (1907); the critique of the notion of neutrality, as exposed in the Buenos Aires conference (1916); and the preference for the British position in the debate between 'Anglophiles' and 'Germanophiles' that took place in South America, more specifically in Brazil (1914-1918) (Cardim 2007: 19). Among Barbosa's contributions, taken to be fundamental for the inquiry into the international dimension of his thought, it is worth stressing - although with appropriate caution - the conceptions contained in his speech at the Buenos Aires conference, where he discusses the issue of war and the meaning of neutrality as practised by countries such as Brazil and the United States.

\section{Rui Barbosa, the moral factor, and the modern concepts of international law}

In 1916, Rui Barbosa was going through a phase of extraordinary public acknowledgement. In that year, the first Brazilian Civil Code was sanctioned by President Venesclau Brás (1914-1918), and in it one notes the deep influences of Barbosa, who accompanied its elaboration from the initial project, during the Campos Sales government (1898-1902), until its final revision when he was official rapporteur for the Special Commission in the Senate. The work resulted in the Report and Rejoinder concerning the redaction of the Civil Code, which, due to the magnitude of his contributions, conferred to Barbosa a degree of eminence as a purist of language and expert jurisconsultus. Among the tributes given to Barbosa at the time of the Code's promulgation, there is his appointment as plenipotentiary and extraordinary ambassador, and as Brazil's representative in the celebrations of Argentina's first centenary of independence.

In Argentina, Barbosa delivered a conference at the Faculty of Law and Social Sciences in Buenos Aires on 14 July 1916. Entitled The Modern Concepts of International Law, the conference was part of the festivities for Argentina's independence, in which Barbosa presented a reading of the history of that Republic, as well as a condemnation of Germany in defence of the democratic governments that were fighting in World War I. In international society, the world was undergoing chaos. The expectations that the war would be quickly won by the Allied forces were completely reversed, and the heavy losses on the battlefield were already being counted in the dozens of thousands daily. It was a war that in two years only had already counted more victims than the Crimean War (1853-1856), the American Civil War (1861-1865), and the Franco-Prussian War (1870-1871) combined. This is the context in which Rui Barbosa prepared his speech. 
During the period that preceded World War I, the great European powers waged an arms race based on the conviction that the prosperity and welfare of a nation depended on its capacity to defend itself against the attacks of other nations, which were ever ready to launch an aggression (Angell 2002). Part of this conventional wisdom was disseminated in virtue of the foreign policy of Kaiser Wilhelm II of Germany, elaborated to substitute for the realpolitik of Bismarck, who had made everything possible to quell the international fear of Germany's growing power by the use of strategic alliances. The proud and confident Kaiser made sure he dismissed Bismarck from the foreign affairs command and dissolved his policies, replacing them with a strategy ostensibly more aggressive, in which national interests were exalted, thereby generating distrust and growing rejection among European powers. In effect, realpolitik was replaced by weltpolitik and was highlighted by the understanding that the great powers derived their status due to colonial possessions and by emphasising what is nowadays called 'unilateralism.' During the lifespan of this government, it adopted the use of aggressive language and intimidation as measures of demonstrating its power. This form of action clearly instilled fear and suspicion among countries and, in face of the relative failure of diplomatic means, led the European powers to start an arms race (Kissinger 2001: 213).

With the outbreak of war, Brazil adopted a policy of neutrality in face of the European conflict. However, due to the active work of the Brazilian League for the Allies - in which Barbosa took part - and of popular manifestations like the one following the torpedoing of the Paraná ship by a German submarine, Brazilian authorities were pressured to sever diplomatic relations with the German Empire in 1917. Barbosa, who was an emphatic defender of the rupture of the neutrality statute, took advantage of the Buenos Aires conference in order to elaborate on and expose the argument according to which the neutral countries, within an environment of armed conflict, suffered as much from war as the belligerent states. Neutrality, in Barbosa's view, did not exempt nations from active obligations. It is here worth noting that at the time, the United States also remained neutral and was subject to an intense debate over the neutrality statute, both in Congress and in the media.

Barbosa's argument essentially insisted that war was an 'irrational act' of the primacy of force over law (Barbosa 1983: 32), and that it stood in intimate relation to two delicate issues: first, a disdain for the juridical-political edifications elaborated at The Hague and, second, the declining state of Western civilization's most important foundation, that is, Christianity (Barbosa 1983: 40, 48). Thus the conference Barbosa proffered is an introspection into the reasons that led him to oppose neutrality: an accurate sense of realism which highlighted the threat, represented by the alliance led by Germany, to the institutions and to the moral ordainment that sustained Western civilization. His thinking, therefore, had nothing to do with the belief that one should avoid war by whatever means and costs. Here the relevance of Barbosa's moral vision regarding international politics starts to appear more clearly.

Between the first and the last part of the conference, Barbosa addressed the topic of war and peace in a quite distinct manner to the general arguments strongly focused on considerations over territorial interests and demands. According to the exposure, his 
point of view does not consider international conflict as a material maladjustment, but rather a moral, or more deeply, a spiritual imbalance of nations. For him, war starts to be prepared in the 'moral surroundings', that is, in 'the air from which the consciences breathe' (Barbosa 1983: 32), which actually means in books and in universities (Barbosa 1983: 18).

Before having left the arms industries, the quarters, and the military staff, this war had accumulated the fluids that eventually encouraged it from the books, inside school, in academia, in the laboratories of human thought. To enter in a struggle with civilization, the force realized that it was necessary to constitute itself as an adequate philosophy, corrupting the minds before subjugating the wills (Barbosa 1983: 32).

The 'moral world', or the 'moral environment', in Barbosa's thought represents the set of ideas and values that guide and establish the judgements and perceptions which, in turn, serve as a foundation for the international juridical-political experiences in a given historical period. According to Barbosa, war does not necessarily maintain a relationship to an alleged incompatibility of material interests merely because material interests have always existed, and at the same time, the European people had previously been, to a great extent, bonded by factors such as race, language affinity, religious traditions, royal family alliances, and intellectual sympathies. Norman Angell, for instance, strives to make this evident by demonstrating the existence of the economic, financial and intellectual ties which interconnected (and still interconnect) the fate of European nations modernised as they were by the advent of both industry and capitalism. Thus, to Barbosa, there existed spiritual causes to conflict, because despite the existence of an international society formed by economic interests and united by interdependence, war was still a reality that caused perplexity.

The foundations of war, according to Rui Barbosa's thought, were supposed to be moving, therefore, in other domains. This was an issue of moral and spiritual order. In other words, it was a direct consequence of the draining out of morality, ignited by the intellectual task of adapting the consciences to the interests of those who defended conflict, a process that presupposed the emptying of the idea of justice from the institutions associated with it (Barbosa 1983: 32). Emphatic and denunciatory as was typical of his style, Barbosa accused militarist thought of having contaminated the European moral realm and of having contributed, drawing from biological arguments and even from pretexts, to the formation of an environment favourably biased towards hostilities and, conversely, unfavourable to international cooperation. Barbosa classified the spread of the militarist movement as perfidious, in that it created a belief that it was possible to completely dissociate national interests from law, morality, and justice. ${ }^{5}$ With this ensuing dissociation, the doctrinaire militarist corps had provoked a sort of 'moral anomy', causing an inversion of the antithesis pax es quaerenda - peace must be sought - and bellum est vitanda - war must be avoided - in the international realm. Now the rule became bellum est quaerenda - war must be sought - and pax est vitanda - peace should be avoided. ${ }^{6}$ 
The reference made by Barbosa to this inversion or moral disorder as a factor of destabilisation of the social and political order is rather uncommon. For him, it is a process of 'de-Christianization of humanity' with tragic consequences; as both men and institutions are de-Christianized, ideas become beclouded, and moral behaviour is inverted (Barbosa 1983: 35-6).

At the disappearance of the ethical-moral fiat represented by Christian faith, the natural order of the international juridical-political realm inverts, distorts, and empties itself through the loss of the most essential moral reference that justifies the existence of institutions capable of alienating the condition of anomy. To Barbosa, due to the suppression of Christian tradition in which the moral principles are anchored, the most powerful states feel free to invest against the least powerful. In the ever-burning rhetoric of Barbosa:

The small states, swept like straws by the scourge of winds, or relentless by the rush of gust that slashes their borders, lose their security or existence while being handed out to the mischances of the fight between the strongest [...] Awful surprises sail in the tenebrous ocean of the unforeseen, where even the clouds of the sky spit out destruction, and where the recesses of the abyss are associated with the exterminating blindness that curdles, at large, with the wrecks of all Christian traditions. Law is denied, justice exiled, truth eliminated, morality contested, honor is prescribed, humanity crucified; the whirlwind of iron attacks the sacred symbols and the arts, the treasures of accumulated science, the grand archives of civilization, the sanctuaries of intellectual labor. Of all of the laws, the only laws that subsist are the laws of necessity, blood, and war. The Gospels are substituted by the religion of steel and powder (Barbosa 1983: 31-2; author's emphasis).

Under this perspective, in the thought of Rui Barbosa Christianity emerges as the threatened doctrine and at same the time as the ground and foundation of the 'harmony of the laws of history', of 'the virtue of international law', of 'the restored balance' and of 'an active neutrality' which should be preserved. The defence of Christianity is mixed, therefore, with the guarantee of security of the juridical-political institutions against the threats of militarist thought and against the unmeasured action of those countries under the leadership of ambitious rulers, such as Kaiser Wilhelm II, to whom, in a way, the condition of anomy would not translate as a threat to human condition, but solely entail a rupture with the undesirable existing order. According to Barbosa, from the suppression of the Christian tradition emerge disorder and anomy, which mean to inevitably thwart all the basic moral principles present in his view of Christianity. It is here worth transcribing another excerpt of Barbosa's very own style of arguing:

In the battlefields, in the invaded cities, in the occupied enemy territory [...], it is this [Christian morality] which protects the quiet homes in the defenseless towns, which safeguards the travelling 
populace of the transatlantic voyages, which does not allow to be sown with mines the waters reserved to pacific commerce, which frees the fishing boats and the floating hospitals from the torpedoes, which prohibits looting, the execution of hostages, the slaughtering of the injured, the poisoning of springs, which protects women, children, the elderly, the sickened, the unarmed. Morality is just this (Barbosa 1983: 40).

In this perspective, the principles of Christianity are seen as moral forces which compel states to act within certain natural boundaries (that is, in accordance to the moral laws which sustain the notion of justice and order), juridical boundaries (which prescribe the actions that preserve honour, trust, and compliance to treaties), and political boundaries (which restrain the impulse of conquest of great states and protect the small ones) even in war, if this becomes inevitable (Barbosa 1983: 31-2, 37-8). In Barbosa, the moral forces can be understood as moral norms or as natural limits. They exist both within the internal organisation of states and among states. The difference is that, in the domestic realm, that is, in civil life, there exist tutelary mechanisms of justice and the constitutions that safeguard them or give them their efficacy. Nevertheless, even inside or outside states, Barbosa understands that moral forces do exist; they can indeed suffer transgressions, but, in a certain way, whatever the present or dominant institutional configuration, they are the essence of justice. Thus,

if these [moral] norms suffered violent transgression lately, it is not because they are mere abstractions. In the internal existence of each state they also break down [...] It is something that is still left to be organized [...] However, while they are not organized, the moral forces do exist, and if they don't shelter people from the contingencies of war, they at least keep, around and above the latter, a set of restrictions and impossibilities which oppose the extreme excesses of unchained militarism (Barbosa 1983: 37-8; author's emphasis).

In the passages of Barbosa's writings, which are rich in biblical metaphors, the interpretations that arise throughout the international dimension of his thought highlight a juridical conception of international relations underpinned with an evident religious-moral ascendance. Religiosity did not obviously occupy a central tenet in Barbosa's thought, but constituted the basis of his educational background, which was characteristic of the Brazilian elite of his time, and which moulded moral and religious expression. According to Miguel Reale, Barbosa was placed inside a Brazilian cultural context dominated by values of Christian traditional spiritualism. Barbosa received those values from his father, João Barbosa, and his mother, Maria Adélia:

His Christianity [originating in family contact] had always been something essential and profound, a conditioning force of his other convictions, be they philosophical, juridical, political. Few men 
would have lived in such an intense manner the religious issue in Brazil, in contrast and liberation (Reale 2014: 5).

His interpretations and his moral philosophy, therefore, emerged from what he had learned from the Sermon on the Mount and from the Gospel teachings of his youth. After all, the threat to peace and to co-operative coexistence among nations were, in his own words, a result of the effacement of the 'Lord's beacon' (Barbosa 1983: 31).

\section{Christ and the idea of civilization in the thought of Rui Barbosa}

The present evidence in Rui Barbosa's argument points towards the existence of a doctrinal content which gives meaning to his thought and to his positions in face of international developments. Although the fact that Barbosa never bothered to be a doctrinal thinker himself is widely familiar, the theoretical and practical consequences of a systematisation of the moral and religious foundations extracted from his writings and actions in the international realm do indeed seem a relevant research endeavour.

From a wide outlook, Barbosa is part of what may be called an intellectual subculture (Galison 1997; Ashworth 2009) which identifies itself with pacifism. As an intellectual movement, pacifism sought to undertake a 'course correction' of international relations. From the end of the nineteenth century to the inter-war period, some authors tried to show evidence that war was futile. They tried to convince rulers that even the small states had their share in constructing international law and believed it was possible to build consensus over a universal juridical norm (Bobbio 1998: 875-7). Writers such as Romain Rolland, Hermann Hesse, and Stefan Zweig were key in the popularisation of pacifism.

Through the content of his writings, the ideas and principles that he defends, and also the intellectuals and the statesmen he quotes, Barbosa shows a strong identification with the exponents of this stream of thought, such as Norman Angell and Woodrow Wilson. Barbosa's argument reveals a careful reading of and reflection on the important thinkers of his time, but whose renown would come about only in the post-war period, as was the case of Norman Angell. The Great Illusion, for instance, was published in 1910, but its reading became popular only after the end of the First World War. In fact, the Norman Angell's name appears frequently at the Buenos Aires conference. ${ }^{7}$ Even though Angell's writings did not express sentiments of religiosity, as was the case for Barbosa, both shared the same concerns with the moral and spiritual tensions manifest in the Western intellectual environment. In Angell, one sees a thought arising in defence of rational arguments and based on concerns of interests and of possible economic and social effects. In Barbosa, however, such arguments acquire a spiritual content, which suggests that, in politics, choices are essentially moral, and that, at the end, there shall be a celestial judgement of such choices. ${ }^{8}$

On the other hand, Barbosa saw closely the consolidation of the United States' international leadership, and, in Brazil, an alliance with that country was seen as beneficial from the political and commercial point of view, and well as morally correct. It is noteworthy that, far more than today, religion in the United States was much more proximate and integrated in the world of politics. ${ }^{9}$ On this issue, which was shared by Barbosa, the 
United States was leading the creation of a continent turned towards peace standing as far as possible from international conflicts and thus free from and inaccessible to the disputes and rivalries of war (Cervo 2002: 184-5). In this context, Barbosa appears as an admirer of Woodrow Wilson, who, to him, would be the leader of the 'free world' and the 'great friend of humanity':

Our peace and security are based, above all, not in the force, indeed colossal, of the United States, but rather in the principles to which the messages of Woodrow Wilson have raised the flag. These principles are the great and true force of the United States, they are the shadow we seek in approximating ourselves to the United States (Barbosa 1988: 112).

It is relevant to explain that this perception was shared everywhere at the time and by the great majority of thinkers. John M. Keynes, in the book he wrote on the Peace of Versailles, argues that Wilson was received in the streets of Paris as both a hero and a prophet, when heading to the conference (Keynes 2002: 24-5).

Placed in a time of great transformations, specifically at the turning point of the uncertainties that led to a world change, Barbosa, at first, interprets the great international issues in their own political and intellectual context, in other words, by the concepts and general motivations of the pacifist school. However, one finds the peculiarity of his thinking in the fact that Barbosa's pacifism is mixed with religious convictions originating in his background education (Reale 2014: 5-6). The doctrinal content found in Barbosa's pacifism is, to a certain extent, the intellectual reaction of someone who witnessed an international society that had been facing increasing dissociation with Christianity in the practical-theoretical realm since the mid-nineteenth century. In his writings, the concerns with the decline of the spiritual energy of the West are an important fulcrum for the construction of his political positions.

Aspects of this moral deterioration of the international realm were well exposed by Hans Morgenthau in his Politics Among Nations. According to him, this process started when Christianity - the Western tradition that sought to 'restrain the power of the strongest in benefit of the weak' - was countered for being seen as emasculated, sentimentalist, and decaying. The opponents of this tradition would have been those who along with the Kaiser Wilhelm II, Nietzsche, Mussolini, or Hitler not only accepted the desire for command and the struggle for power as underlying social facts, but who actually praised their manifestations and advocated the absence of restriction towards the use of force as a reinvigorating factor to societies and a norm for the conduct of individuals (Morgethau 2003: 422).

The truth is that international relations has always been considered an instance alien to faith-based judgements, while both ethics and morality have been widely considered manifestations characteristic of the judgement of domestic and individual behaviours (Martins 2001: 5). On the other hand, it is true that international relations theory, in its more recent strands, has reconsidered the relevance of ethics and morality. From the end of 
the 1990's onward, there emerged what many have called the ethical turn in International Relations (Linklater 1999). Moreover, critical theory, normative theory, post-colonialism, feminism, and post-structuralism are all approaches guided by intense and serious ethical and moral considerations. When claiming that international relations has always been considered a realm alien to faith and morality, we are referring to an understanding made by tradition. Classical realism always considered that justice does not perform a central role in international relations because such instance is organised around the principles of force and power politics. After all, when units interact guided by considerations of force and power, justice becomes reduced to the comprehension made by Thrasymachus in Plato's Republic: 'Justice is the convenience of the strongest.' In this direction, the Melian dialogue described by Thucydides in his History of the Peloponnesian War is definitive:

For of the Gods we believe, and of men we know, that by a law of their nature wherever they can rule they will. This law was not made by us, and we are not the first who have acted upon it; we did but inherit it, and shall bequeath it to all time, and, we know that you and all mankind, if you were as strong as we are, would do as we do (Tucídides 2001: 351).

In fact, generally speaking, since the sixteenth century there has been a theoreticalpractical consolidation in favour of the idea of a raison d'état for which there remains no consideration for morality and ethics, a process which inevitably supposes the progressive departure of state activity from religious precepts or of any religious-moral observation concerning reality. Remarkable aspects of this conception were enshrined in Chapter XV of Machiavelli's The Prince, where he professed war to be just another instrument of the prince's virtú, settling the foundations of the distinction between public and private ethics and between religious and political ethics, thus constituting truly opposing pairs (Maquiavel 1983: 63-4).

According to Jean Bodin, a thinker with strong religious sentiments, Machiavelli was a clear example of the irresponsible philosopher, who had instilled in The Prince the poisoning of atheism and the ignorance of the norms and of the moral laws, and therefore contributed to the disruption of continuity of the advice elaborated by the wise par excellence in the realm of politics - Socrates, Plato, and Aristotle (Bodin 2011: 59-63). In modern political science, it is considered that one of the most notable contributions of The Prince is the understanding that politics does not have the purpose of transforming men into virtuous beings, or that the state should have some underlying ethical or religious purpose, but should instead simply serve as an instrument of the societies in the sense of promoting collective goods such as prosperity and domestic/foreign security.

The trend towards separating the realm of politics from that of faith succeeded throughout the centuries and was reinforced by the consolidation of the modern national state, a political organisation which came to occupy the social and moral vacuum left by the retreat of the Respublica Christiana (Bull 2002: 37-8). ${ }^{10}$ In the passage from the nineteenth to the twentieth century, two developments reinforced the deterioration of the religious dimension in international politics: (1) the transformation of accountability 
in matters of foreign commerce from aristocratic to democratic; and (2) the replacement of still strong universalist paradigms by nationalist patterns (Morgenthau 2003: 450-63). In reality, the process of separation between state and church was consolidated in the nineteenth century, a process to which Rui Barbosa also contributed. In fact, the Brazilian Constitution of 1824 declares in its $5^{\text {th }}$ article that 'the Roman Catholic Apostolic Church shall continue to be the Empire's Religion', while the first Republican Constitution of 1891, in its $72^{\text {nd }}$ article, only assures Brazilians the freedom of religious faith.

In such an environment where religious unity was ceasing to be a uniform moral foundation for political behaviour, it was inevitable that intellectuals such as Rui Barbosa would start to confront notable divergences around the meaning of actions and motivations concerning the essential phenomena in international relations. Many of them positioned themselves in a manner quite similar to Morgenthau's account:

If everything we needed to know about international politics were limited only to the motivations behind power struggle and to the mechanisms whereby it operates, the international sphere would most certainly appear like the state of nature of a 'war of all against all' as described by Hobbes. International politics would thus be governed by those considerations of political opportunism of which Machiavelli left us the most acute and sincere account. In such a world, the weak would be completely left at the mercy of the stronger (Morgenthau 2003: 421).

In this framing, one can sense the way in which Barbosa indicates an audacious and original deontological solution to the issue by recovering elements of religious morality. For Zingano, deontological systems work the idea of duties that can be previously determined; it would be up to the moral agents to know and apply them in every situation. In this system, religion is a source of inspiration, for it provides rules and laws to be observed under the form of a moral legislation, for instance Christianity, Islam, Hinduism, the Ten Commandments, the Hammurabi Code, and the Analects. What is relevant to note here is that, within a deontology, there is a law, a revelation, a commandment, or a rule which dictates what should be done and under the form of a duty to be accomplished; 'morality is seen, in this perspective, as properly consisting in a legislation' (Zingano 2013: 25).

Terms such as 'moral forces,' 'the gospel of Christ,' 'moral values,' 'moral duty,' 'obligation,' and 'consciousness' appear insistently in his writings and, at times in which pacifist movements mobilise in defence of politics as a realm of action destined to protect and incent humanity's general interests, it is common that the moral and religious attributes constitute the rhetorical basis for the defenders of peace. In such periods, discourses generally resort to symbols and terms strongly highlighted with a transcendent meaning - such as 'God,' 'soul,' 'consciousness,' 'truth', 'honesty,' 'virtue,' 'commiseration,' 'domestic/foreign obligation,' and 'love thy neighbour as yourself' - thereby justifying a kind of humanisation of international politics (Angell 2002: 148; Almeida 2009: 39). 
Far from attributing to religious concepts a mere rhetorical position, Rui Barbosa uses them as the essential content of his opposition to the secular distinction which is reinforced by political events and developments and to the distinction between public and private, as well as political and religious ethics. With a deontological conception of international politics, Barbosa seeks to efface the distinction between a valid public morality and one only applicable to the religious and individual realm. For him, there is no such a thing as two moralities or justices. Be it on the individual, state, or international level, morality is, fundamentally, just one: the doctrinal morality grounded in the natural laws of human consciousness.

It should not be said, therefore, as has been the case, that in the realm whereby the politics of the major powers stirs, the usual notions of doctrinal morality are only received after being altered by a rude alloy of selfishness. There are not two moralities, the doctrinal and the practical. Morality is just one: that of human consciousness, which doesn't waver in discerning between law and force. Interests may transitorily blur this organ of internal vision: they may blur it by means of the relations between peoples, as in the relations between individuals, in the commerce between states as well as between individuals, in government as in courts, in the realm of international politics as in the civil and penal codes. These disturbances, anomies, and crisis, notwithstanding, don't prove the inexistence, among ourselves, individually and collectively, of a sense of human morality, or that its formulas are mere theories (Barbosa 1983: 38).

Rui Barbosa's position is indeed audacious, since it highlights a large distance from the fundamental proposition elaborated by Emer de Vattel. To Vattel, the law of nature equally obliges men and state. However, in order to know the rights and duties of states it wouldn't be enough to know what the law of nature prescribes, in terms of rights and duties, to individuals. Because states are a diverse set of actors, that is, since they possess a distinct nature - when compared to the individual - it is necessary to promote a 'just and meditated application of the natural law to the affairs and the conduct of nations or of sovereigns' (Vattel 2003: LXXI). Barbosa seems to understand this issue from another angle: in order to know what is right or wrong in the international political realm, or rather, to comprehend the rights and duties of nations, it is enough to consult the forum of conscience. In some way or another, the position held by Barbosa appears in Francisco de Victoria's De Indis. To Victoria, every judgment concerning conduct is made by the constant reference to human consciousness (Vitória 2014). Thus there cannot exist, according to Barbosa, two moralities, one for the state, the other for individuals. Under both peace and war, morality can only be one - the morality of Christ:

Love thy neighbor as yourself. Dilliges proximun tuum sicut te ipsum.

This time, nations came to seriously perceive that it is also addressed 
to them, none less than to the individuals, the verb of the supreme pacifier, the verb of the Crucified (Barbosa 1988: 39-40).

Under this view, and placed in a religious atmosphere of re-encounter between faith and reason, actions are seen as amounting to a divine realm, and the international duties of a country and of international society therefore become fully clear, including: to shelter the poor, to protect the small, to curb the rich, to restrain the strong, and to protect the weak, restoring to justice its true meaning. In summary, Barbosa endeavoured to find the general principles that could provide support and security to the juridical-political actions of nations (Garcia 1996: 121). In the international dimension of his thought, such principles are constituted at the meeting point between pacifism and Christianity, and are associated with the very conception of the state as a purposeful institution and capable of filling human needs:

Without religion, without morality [...] the state does not subsist, because it lacks the means, the environment, the object of its functions, which is to establish an atmosphere of security, justice, and peace, whereby the satisfaction of all these human needs, and whereby all manifestations of human activities fully develop and rotate fully (Barbosa 1983: 46).

\section{Final remarks}

The international dimension of Rui Barbosa's thought can be organised according to the type of approach. In some cases, it is eminently technical such as the writings contained in the Annals of the Second Hague Conference, the Interstate Taxes, the Civil Code, and the Law of the Amazons to the Septentrional Acre, which mainly reveal his vast juridical expertise. At other times, this dimension expresses its liberal-progressivist political views, as denoted in the pronouncements which compose his Civilian Campaign, The Foreign Office, Interstate borders, Minas $x$ Werneck Issue, and The São Paulo Northern Railroad Company Case. In cases which entail more critical topics, above all when it refers to the dilemma between peace and war, Barbosa's thought reveals its doctrinal facet, fraught with moral standings and grounded in religious visions, which manifests itself more ostensibly, such as in his discourse at the ceremony of Argentina's centenary of independence.

In fact, the technical, liberal-progressivist, and doctrinal approaches appear to some extent combined in Barbosa's work, but what one infers on glimpsing closely enough, nonetheless, is that the latter approach is the least identified and highlighted among scholars who study his thought. Some of Barbosa's writings, such as the preface to the Fall of the Empire, the Discourse at Anchieta School, and Prayers to the Youth, denote a remarkable doctrinal emphasis underlying his reflections and focus on intentions and concerns of separating right from wrong, the desired from the undesired. In the First Works and in Poetries, in Political Works and in Juridical Works, and above all in the long series of documents correlated to international relations included in the Parliamentary Discourses, 
in Electoral Excursion, in Great War, in Buenos Aires Embassy, in Letters from England, in Greetings to Robert Bacon and, naturally, in Modern Concepts of International Law, one sees a moral-religious mindset confused with the evocation of the problem of war, and which serves to support his visions on international politics and the foreign affairs of his country. In these writings, words such as 'benevolence,' 'Christ's charity', and 'universal solidarity' acquire special relevance and serve as the basis to his open defence of a juridical equality among nations, the constitution of a great unity of all nations in the American Continent, and of arbitration and conciliation as forms of conduct in international affairs. At the same time, they also serve to vehemently condemn the war of conquest and a whole generation of European philosophers and statesmen of the nineteenth century who, according to Barbosa, worshiped, openly or covertly, the recourse to force in order to promote their own interests and politics of expansion. Besides the already mentioned Friedrich Nietzsche and the Kaiser, it is worth mentioning the fact that, at the start of the twentieth century, although the environment was not as favourable to expansionist and revisionist policies, history still registered public celebrations in the main capitals of Europe when the First World War broke out.

Noting the existence of a religious dimension in the different essays, reports, and discourses regarding the international dimension of Rui Barbosa' thought, one is compelled to observe that this dimension goes beyond a mere rhetorical resource serving to contextualise his ever purposeful visions: from these writings, international relations and its dilemmas could only be appropriately understood as part of a broader moral and divine order of being. From the work The Modern Concepts of International Law it can be stressed that, to Barbosa, the spiritual tension of international society is at the heart of the debate. It is clear that this work and others of his writings share a juridical-political reasoning of its epoch; however, his religious-moral mindset also acquires primacy, centrality, and explanatory power as an element that justifies and conduces to yet another realm of the same juridical-political reality, and then becomes a fulcrum from which to point fragilities and possibilities.

How does a religious-moral mindset appear in the international dimension of Rui Barbosa's thought? It is indeed very hard to know, at first, if this conception doesn't signify, instead, a natural reaction of a man sensible to the drastic changes in the world and who, after seeing a war with helpless tragedy and of worldly scale, appeals to the only available medicine under such circumstances: 'the appeal to the heavens.' According to Evaristo de Moraes Filho, Barbosa was not part of the nihilist generation, who denied God and frontally opposed Socratic scholars and Christian morality. In his own words,

Barbosa, who until the start of maturity did not escape certain anticlerical influence, lining up even amongst the most impudent adepts of religious freedom and critics of Ultramontanism, such as Tavares Bastos, Saldanha Marinho, Macedo Soares, among others, saw an increasingly mystical feeling towards God, Christianity, and faith growing within him. As an old man, horrified in face of war, [and] with whatever may signify destruction and death, the invocations of 
God are numerous and repeated always in a dramatic sense, of hope and humbleness (Moraes Filho 1981: XIX).

Américo Jacobina Lacombe, author of various books about Rui Barbosa, considered that his religious attitudes were generalised during his generation. This attitude derives from an anti-Tridentine Christianism and the old Döllinger Catholics, ${ }^{11}$ who saw in Pope Pius IX and in the Society of Jesus the destroyers of the true faith. According to him, 'at the end season of the Empire nearly the totality of our public men thought this way' (Lacombe 1981: X).

In order to better grasp the religious dimension in Rui Barbosa, it is worth resorting to events in his biography that suggest a profoundly religious education which, contrary to what had happened to many intellectuals of the same generation in Brazil and elsewhere, he absorbed and incorporated as a way of thinking. His father, João José Barbosa de Oliveira, habitually read the New Testament with his sons in a copy that is still held at the Rui Barbosa's House Foundation. ${ }^{12}$ As a young man, Barbosa repelled religious scepticism, as can be noted in this solemn declaration of faith in his First Works.

On these occasions of over-human despair, what would we be if the inspirations our mothers know to spill in the young heart of their children didn't avail, this indelible belief in the grand division, in future life, in the infallibility of Providence. I speak to you in such terms for I have already drunk from this chalice. Countless times have I judged the omnipotent and absolute intelligence; countless times have I awaited finding in the recesses of Science, this Science that is already so large, the key to the world's Arcanum, the sane, complete and abundant nourishment of the soul, the generous balsam for the heart's grievances. God, notwithstanding, reached His arms towards me and seared the flower of my pride [...]. Then, I found the books to be deaf, reason deaf, and philosophy sterile (Barbosa 1951: 160).

To Lacombe, there is not one declaration of agnosticism in all of Barbosa's writings since his appearance in public life: 'what could those subtle distinctions of regalism, collaboration, separation of powers, infallibility, jurisdiction over dogmatic definition, and agony from the continuous and appalling departure of the popular masses from religious life possibly mean to an atheist?' (Lacombe 1981: XII). There is no falsehood, then, concludes Lacombe, in Rui Barbosa's religious tone (Lacombe 1981: XV).

Besides Barbosa's natural inclination to treat political issues with a tone of moral philosophy, another factor might in fact have strengthened his support of such a posture: the intellectual and political contexts in which he stood. It is possible to affirm that, in Brazil, since the Second Regency, ${ }^{13}$ a moral and normative position regarding international issues has developed, which still thrives. This derives from the '[...] moderates averse to the politics of force, against intervention and resistance through force, prone to negotiation and the super-dimensioning of diplomatic action. Among its most eminent representatives 
were Antônio Limpo de Abreu (Viscount of Abaeté), Pedro de Araújo Lima (Marchese of Olinda) and João Lins Vieira Cansanção de Sinimbu (Viscount of Sinimbu)' (Cervo 2002: 68).

It is curious to note that the current interpretation of Rui Barbosa's international thought (through Garcia, Amorim, Lafer, and Cardim) associates him with the rationalist tradition of International Relations Theory, also called 'Grotian tradition', in reference to the seventeenth century Dutch jurist, Hugo Grotius. Despite this, a considerable part of his writings seems to hold more affinity with what Martin Wight entitled the 'fourth tradition' of International Relations. Besides the three conventional traditions - Realism (Machiavellian), Rationalism (Grotian), and Revolutionism (Kantian) - the young Wight started a tradition later called 'Inverted Revolutionism' (Quaker Christianity) (Wight 1936; 1991). Part of this formulation was due to the fact that Wight had witnessed, during the inter-war period, a moment of strengthening of a tradition of Christian thinkers who wrote about culture, society, and international politics. This tradition was a reaction to the movement of secularisation undertaken by the vast majority of the intellectual elite who took for the granted the disappearance of Western Christian tradition. Martin Wight, an intellectual with a religious background, took part in this movement in defence of the foundations of Christian tradition as a means of orienting a solution to the arduous task of conciliating morality, faith, and international issues (Thomas 2001), resulting in a normative approach called the 'fourth tradition, an audacious line of inquiry combining reason, faith, and morality with reflection on foreign policy and international relations.

In reality, it is surprising how Barbosa's spiritual force is transferred from the intimate domain to public life, and how he moves from the New Testament to later occupying the pulpit and the feather. Barbosa had always been, first of all, a man of action, and hence, his written or spoken words are that of a tribune who vehemently defends and proposes paths of action. Even in the most puzzling issues, his arguments are not that of a 'scholar,' who raises questions and analyses the most controversial points of view. His words are always faith-based assertions of the paths he believes to be the best and the most righteous.

\section{Notes}

1 The Old Republic refers to a historical period in Brazilian political life dating from 1889 to 1930.

2 Minister of Foreign Affairs from 1902 to 1912.

3 See note 4.

4 The idea of a constitutive subject who is conscious of certain values and principles is a solid article of faith in Brazilian diplomatic thinking. This tradition of thought believes in the existence of a set of values and ideas which historically support the international actions of Brazil. Its exponents do not doubt the existence of 'certainties' and 'truths' attributed to a constitutive subject, an omnipresent agent behind the formulation of the activities, of the doings and the becoming of the country's international affairs. A subject whose existence and history is based on 'unquestionable compliance with International Law, the non-recourse to force in the resolution of disputes between states, respect for non-interference in another country's domestic affairs, the observance of human rights and a set of values which are proper to our civilizational heritage, are all constitutive of Brazilian diplomatic activity' (Almeida 2013: 15). However, it is one thing to believe in ideas and in a set of ahistorical values and principles, i.e. in the existence of 'a single language articulated by political leaders and intellectuals' (in different historical periods) and accepting a 'historical 
pattern which insists in the arrow of time of Brazilian international insertion' (Saraiva 2014: 10). It is quite a different thing, however, to perceive that ideas and thinking on Brazil's international politics may not be as crystal clear, not even to their formulators, as in the case of Rui Barbosa, because ideas and thoughts are formed under tough struggles, in very specific cultural and intellectual contexts, under spontaneous movements of spirits that feel, dream, imagine, and desire within their fields of experience and, without premeditation, end up leaving a horizon of expectations. When turning to Barbosa or to other classical figures, Brazilian diplomatic thinking seeks to search for the 'roots' of the principle of juridical equality among nations or the 'birth principle' of multilateralism. This is problematic, however, since this movement ends up reifying the 'assurances' and 'official truths' which may, ultimately, conceal interesting and genuine ideas. This is the case of the Buenos Aires conference. The traditional readings of the conference do no point to a religious or moral dimension in Barbosa's international thought in that context, but instead they only refer to the conference as a moment of the formulation of the thesis of neutrality. Thinkers like Celso Amorim (2007), Celso Lafer (2000), and Carlos Henrique Cardim (2007) all direct their attention to Barbosa under the latter form (regarding Brazilian diplomatic thought, see Pimentel 2013; Almeida 2013: 15-38; Cardim 2007; Saraiva 2009; 2014; Cervo 2008; regarding the issue of subject, see Muñoz 2015; regarding critical and post-structural thought, see Walker 2013; regarding Brazilian critical diplomatic studies or critical thinking on Brazil's foreign policy see Jatobá 2013; Luciano 2013; Muñoz 2015; and regarding the historical method, see Koselleck 2006).

5 Compare Barbosa (1983) in The Modern Concepts of International Law with Angell (2002) in The Great Illusion: 148.

6 The sociological concept of anomy refers to a state of being where there is a lack of purpose and loss of identity. The term was coined by Émile Durkheim in his book Suicide (1897), which employs the term to explain how and why something in a society does not function in harmony. In antiquity, the word anomy was used by Thucydides, in The Peloponnesian War, to describe the moral and political consequences of Athens's internal exodus provoked by war. According to Xavier (2002: 121), 'Pericles, at his first discourse at the start of the Peloponnesian war, asks the population living outside the walls of the Polis to leave their lands and homes and reach inside Athens. The internal exodus was large and the hygienic and sanitarian conditions were very much affected [...] In this context [...] a plague erupts, decimating part of the population. The historian [Thucydides], then, makes a famous description rich in clinical details of the manifold symptoms and even of the effects of contamination. However, what seems to be worrying the most are the moral and political consequences of the plague: "Generally, the plague was, inside the town, the origin of the increasing moral disorder [anomias] [...]"' (Excerpt and translation from Gabriel Geller Xavier, from the work of Thucydides, La guerre du Péloponese: livre II, cap. LIII. Translation: Jacqueline de Romily. Paris, Les Belles Lettres, 1962, p. 39).

7 Angell's work was received and conceptually adapted by Barbosa. One may compare the content of the political thesis of both men and verify, for example, how many times Barbosa directly quotes Angell. Aspects of this intellectual interaction were dealt with in the panel 'The great Illusion: a hundred years later', during the third national meeting of the Brazilian Association of International Relations (2001).

8 A similar address is seen in the second inaugural speech of Abraham Lincoln (1865), where he argues that in the American Civil War both sides invoked the same God, and hence, the Creator could not have been on both sides simultaneously, or maybe had been, and war would then have been a punishment imposed to both sides in order to expiate the sin of slavery (Morris 1964: 162-4).

9 Max Weber wrote his famous work on Protestant ethics and the spirit of capitalism at the start of the twentieth century and, to a large extent, the book resulted from his observation of American society. The first edition was published in 1904, and the second, which brought about a number of additions and became more popular, was published in the next year, after Weber had made a trip to the United States.

10 According to Herz, the presence of a moral vacuum among national states derives from a tradition that finds its roots from Machiavelli to Waltz and which will not be easily discarded (Herz 1997).

11 Both terms 'anti-Tridentine' and 'old Döllinger Catholics' refer to the movement initiated in the region of Utrecht, at the end of the nineteenth century, when national Catholic churches started going openly against the First Vatican Council. The 'old Catholics' from Utrecht proposed a return to the beliefs of the primitive Catholic church, contested the dogma of papal infallibility, and defended the conduct of ritual in the vernacular language. 
12 The Rui Barbosa's House Foundation is an institution aimed at preserving and disseminating the legacy of Rui Barbosa. It is situated in the very same house in which Barbosa lived between 1885 and 1923, located in the Botafogo district, in the city of Rio de Janeiro.

13 The Second Regency constituted a political regime in Brazilian history dating from 1840 to 1889.

\section{References}

Almeida, Paulo Roberto de. 2013. 'Pensamento diplomático brasileiro: introdução metodológica às ideias e ações de alguns dos seus representantes'. In Vicente de Sá Pimentel (ed). Pensamento diplomático brasileiro: formuladores e agentes da política externa (1750-1950). Brasília: FUNAG. pp. 15-38.

Almeida, Rafael Salatini de. 2009. 'Relações Internacionais na filosofia política moderna (séculos XVI-XVIII)'. Doctoral Thesis, University of São Paulo (USP).

Amorim, Celso. 2007. A diplomacia multilateral do Brasil: um tributo a Rui Barbosa. Brasília: Fundação Alexandre de Gusmão.

Angell, Norman. 2002. A grande ilusão. Transl. Sérgio Bath. Brasília and São Paulo: Universidade de Brasília, Instituto de Pesquisa de Relações Internacionais, and Imprensa Oficial do Estado de São Paulo.

16(1): 33-51.

2002. 'Did the realist-idealist Great Debate really happen?' International Relations,

Barbosa, Rui. 1988. 'A Grande Guerra'. In Rui Barbosa. Obras Completas de Rui Barbosa. Vol. XLIV, Tomo I, Rio de Janeiro: Fundação Casa de Rui Barbosa.

. 1983. 'Discursos na assembleia provincial da Bahia'. In: Rui Barbosa. Obras Completas de Rui Barbosa. v. V, Tomo I. Rio de Janeiro: Fundação Casa de Rui Barbosa.

. 1951. 'Discurso em Sociedade Acadêmica Beneficente'. In: Rui Barbosa. Primeiros Tra-

balhos. Obras Completas de Rui Barbosa. v. I, Tomo I, Rio de Janeiro: Ministério da Educação e Saúde.

1983. Os conceitos modernos do direito internacional. Rio de Janeiro: Fundação Casa de Rui Barbosa.

Bodin, Jean. 2011. Seis livros da república. Transl. Jose Carlos Orsi Morel. São Paulo: Editora Ícone. Book One.

Bobbio, Norberto, Nicola Matteucci and Gianfranco Pasquino. 1998. Dicionário de Política. Transl. Carmen C Varriale et al. Brasília: Universidade de Brasília.

Bull, Hedley. 2002. A sociedade anárquica. Transl. Sérgio Bath. Brasília and São Paulo: Universidade de Brasília, Instituto de Pesquisa de Relações Internacionais, and Imprensa Oficial do Estado de São Paulo.

Cançado Trinidade, Antonio A. 2002. O Direito Internacional em um Mundo em Transformação. Rio de Janeiro: Renovar.

Cardim, Carlos Henrique. 2007. A raiz das coisas-Rui Barbosa: o Brasil no mundo. Rio de Janeiro: Civilização Brasileira.

Cervo, Amado and Clodoaldo Bueno. 2002. História da política exterior do Brasil. Brasília: Universidade de Brasília. 
2008. 'Conceitos em Relações Internacionais'. Revista Brasileira de Política Internacional, 51(2): 8-25.

Fausto, Boris. 2012. Revisão de Rui. Available at: <http://www1.folha.uol.com.br/fsp/opiniao/ fz1511199907.htm.> [accessed on 25 October 2016].

Galison, Peter. 1997. Image and Logic: a Material Culture of Microphysics. Chicago: University of Chicago Press.

Garcia, Eugênio Vargas. 1996. 'Aspectos da vertente internacional do pensamento político de Rui Barbosa'. Textos de História, 4(1): 103-24.

Heilbroner, Robert and William Milberg. 1995. The Crisis of Vision in Modern Economic Thought. Cambridge: Cambridge University Press.

Hirschman, Albert O. 1986. A Economia como Ciência Moral e Política. São Paulo: Editora Brasiliense.

Herz, Mônica. 1997. 'Teoria das Relações Internacionais no pós-Guerra Fria’. Dados, 40(2). Available at: <http://www.scielo.br/scielo.php?script=sci_arttext\&pid=S0011-52581997000200006> [accessed on 25 October 2016].

Jatobá, Daniel. 2013. 'Los desarrollos académicos de las Relaciones Internacionales en Brasil: elementos sociológicos, institucionales y epistemológicos'. Relaciones Internacionales 22 (Feb-Mar): $27-46$.

2013. 'Repensar y rehacer la realidad contemporánea tras la expansión filosófica de las Relaciones Internacionales'. Relaciones Internacionales 24 (Oct-Jan): 109-27.

Keynes, John M. 2002. As Conseqüências Econômicas da Paz. Transl. Sérgio Bath. Brasília and São Paulo: Universidade de Brasília, Instituto de Pesquisa de Relações Internacionais, and Imprensa Oficial do Estado de São Paulo.

Kissinger, Henry. 2001. Diplomacia das grandes potências. Transl. Saul S Gefter and Ann Mary Fighiera Perpetuo. Rio de Janeiro: F Alves.

Koselleck, Reinhart. 2006. Futuro passado: Contribuições à semântica dos tempos históricos. Transl. Wilma Patrícia Maas and Carlos Almeida Pereira. Rio de Janeiro: Contraponto and Editora PUCRio.

Lacombe, Américo Jacobina. 1981. 'Introdução'. In Rui Barbosa. Discurso ao colégio Anchieta. São Paulo: Fundação Casa de Rui Barbosa.

Lafer, Celso. 2000. 'Brasil: dilemas e desafios da política externa'. Estudos avançados, 14(38): 260-7.

Linklater, Andrew. 1999. 'The evolving spheres of international justice.' International affairs, 75(3): 473-82.

Luciano, Bruno Theodoro. 2013. 'Abstrações imperfeitas: o uso de teorias e de conceitos em Relações Internacionais.' Século XXI 4(1): 73-88.

Maquiavel, Nicolau. 1983. O Príncipe. Transl. Lívio Xavier. São Paulo: Abril Cultural.

Martins, Estevão de Rezende. 2001. 'Ética e Relações Internacionais: elementos de uma agenda político-cultural.' Revista Brasileira de Política Internacional, 44(2): 5-21.

Moraes Filho, Evaristo de. 1981. 'Prefácio'. In Rui Barbosa. Obras Completas de Rui Barbosa. Embaixada a Buenos Aires. v. XLIII, Tomo I. Rio de Janeiro: Fundação Casa de Rui Barbosa. 
Morgenthau, Hans. 2003. A política entre as nações: a luta pelo poder e pela paz. Transl. Oswaldo Biato. Brasília and São Paulo: Universidade de Brasília, Instituto de Pesquisa de Relações Internacionais, and Imprensa Oficial do Estado de São Paulo.

Morris, Richard B. 1964. Documentos Básicos da História dos Estados Unidos. Rio de Janeiro: Fundo de Cultura.

Muñoz, Luciano da Rosa. 2015. 'O sujeito nas Relações Internacionais: um problema epistemológico.' Universitas: Relações Internacionais 13(1): 1-13.

Pimentel, Vicente de Sá (ed). 2013. Pensamento diplomático brasileiro: formuladores e agentes da política externa (1750-1950). Brasília: FUNAG.

Reale, Miguel. 2014. 'Posição de Rui Barbosa, no mundo da Filosofia. Notas de estudo para a compreensão de uma trajetória espiritual'. Available at: <http://www.tjrs.jus.br/export/poder_judiciario/ historia/memorial_do_poder_judiciario/memorial_judiciario_gaucho/revista_justica_e_historia/ issn_1676-5834/v4n8/doc/04_Miguel_Reale.pdf.> [accessed on 25 October 2016].

Saraiva, José Flavio Sombra. 2009. Concepts, Histories and Theories of International Relations for the 21 $1^{\text {st }}$ Century: Regional and National Approaches. Brasília: Premius and Instituto Brasileiro de Relações Internacionais.

2014. 'Autonomia na inserção internacional do Brasil: um caminho histórico próprio.' Contexto Internacional, 36(1): 9-41.

Thomas, Scott M. 2001. 'Faith, history and Martin Wight: the role of religion in the historical sociology of the English School of International Relations.' Royal Institute of International Affairs, 77(4): 905-29.

Tucídides. 2001. História da guerra do peloponeso. Transl. Mário da Gama Kury. Brasília and São Paulo: Universidade de Brasília, Instituto de Pesquisa de Relações Internacionais, and Imprensa Oficial do Estado de São Paulo.

Walker, Robert (RBJ). 2013. Inside/outside: Relações Internacionais como Teoria Política. Rio de Janeiro: PUC-Rio and Apicuri.

Wight, Martin. 1936. 'Christian pacifism.' Theology 33(198): 367-8. 1991. International Theory: the three traditions. London: Leicester University Press.

Vattel, Emer de. 2004. O direito das gentes. Transl. Vicente Marotta Rangel. Brasília and São Paulo: Universidade de Brasília, Instituto de Pesquisa de Relações Internacionais, and Imprensa Oficial do Estado de São Paulo.

Vitória, Francisco de. 2014. 'Sobre os índios recém-descobertos'. Available at: <http://pensadoresclassicosedebatescontemporaneos.files.wordpress.com/2014/01/vitoria-de-indis.pdf.> [accessed on 25 October 2016].

Xavier, Gabriel Geller. 2002. 'Tucídides e as Relações Internacionais: um breve ensaio.' In Raphael Spode and Gabriel Geller Xavier (eds). Abordagem Clássica das Relações Internacionais. São Paulo: Conceito Editorial. pp. 107-53.

Zingano, Marco. 2013. As virtudes morais. São Paulo: Martins Fontes.

\section{Acknowledgements}

This paper presents the partial result of ongoing doctoral research that started in 2013 at the Institute of International Relations at the University of Brasilia (UnB). I would like to dedicate this paper 
to and thank some very important people who made it possible. To Professor Eiiti Sato, whom I thank for formal supervision of this research, I am indebted for much of what I have learned over recent years. I also thank professor Estevão Chaves de Rezende Martins for his support for and comments on this research. I am indebted to him for the receptive atmosphere for ideas that has given me a very clear dimension of what the research can or should approach. My gratitude also goes to Professor Frederico Seixas Dias, who has followed my steps since my preparation for the project to the more definitive structuring of arguments, some of which have been presented in this paper. I also am indebted to him for a distinct approach to the history of concepts. In addition, I thank Professor Gabriel Geller Xavier for his important contribution to and constant dialogue on the history of philosophy and ethics. My thanks also go to Professor Luciano Muñoz for engaging with my arguments and for the constant dialogue that allowed me to foresee both the task of research and the field of International Relations through a new critical prism. I am also grateful to my colleague Rodrigo Duque Estrada for translating this paper and for his insightful commentaries regarding its form and content. Finally, I thank CAPES for the doctoral scholarship, and the Rui Barbosa's House Foundation for its kind support and the donation of books for this research.

\section{About the author}

Raphael Spode is a $\mathrm{PhD}$ candidate in International Relations at the University of Brasília (IREL/UnB, Brazil). He is co-editor of Abordagem Clássica das Relações Internacionais (Conceito 2012) and co-author of Hobbes e Locke nas Relações Internacionais (Juruá 2013). He lectured the courses Introduction to the Study of International Relations and International Relations Theory at the University of Vale do Itajaí (UNIVALI, Brazil), where he was headmaster. He also lectured International Relations Theory at the Federal University of Santa Catarina (UFSC, Brazil). Currently, he is Professor of International Relations Theory and Political Science at the University Center of Brasilia (UniCEUB, Brazil), where he coordinates the Research Centre for Political Thought and Humanities.

Received on 15 February 2016 and approved for publication on 9 August 2016.

\section{(cc) BY-NC} https://creativecommons.org/licenses/by-nc/4.0/ 
